\title{
The Effects of Iron Compounds on the Virulence of Vibrio anguillarum in Japanese Eels and Ayu
}

\author{
Toshihiro NaKaI, Tsuyoshi Kanno, Erlinda R. CRUZ*, \\ and Kiyokuni Muroga \\ Faculty of Applied Biological Science, Hiroshima. \\ University, Fukuyama 720, Japan
}

(Received March 20, 1987)

\begin{abstract}
When Japanese eels (Anguilla japonica) were injected intramuscularly (IM) with ferric ammonium citrate (FAC) at a sublethal dose of $10 \mu \mathrm{g} / \mathrm{g}$ and followed by IM-injection with various doses of Vibrio anguillarum, FAC injection enhanced greatly the virulence of the pathogen to eels, lowering the $\mathrm{LD}_{50}$ value from $10^{7.8}$ to $10^{4.2} \mathrm{CFU} / 100 \mathrm{~g}$. Similar effects were obtained with ferrous sulfate and ferric chloride in eels. However, such a virulence-enhancing effect of FAC was scarcely observed in ayu (Plecoglossus altivelis), which has high susceptibility to the pathogen by nature. It was also found that addition of FAC $(10 \mu \mathrm{g} / \mathrm{ml})$ in fish sera accelerated the bacterial growth in vitro but the effect was much greater in eel serum than in ayu serum. The results of these in vivo and in vitro experiments demonstrated that the availability of free iron in host fish would have a significant influence on the pathogenesis of $V$. anguillarum infection.
\end{abstract}

Vibriosis caused by Vibrio anguillarum prevails in various freshwater and marine fishes in the world (EvelyN, 1984), and especially in cultured ayu (Plecoglossus altivelis) with devastating mortality in Japan (AOKI and KITAO, 1978; Jo, 1981). There have been many investigations on the disease and the pathogen (HORNE, 1982), and recent works have been concentrated on the virulence factors of the organism such as extracellular and intracellular toxins (UMBREIT and TRIPP, 1975; Munn, 1980; Kodama et al., 1985; Inamura et al., 1984, 1985), resistance to serum bactericidal action(Trust et al., 1981), hemagglutinin (TORANZO et al., 1983), adhesion to host tissues (HORNE and BAXENDALE, 1983), and efficient iron uptake system regulated by a plasmid (CROSA, 1980).

It is well known that the free iron plays a vital role in the proliferation of pathogenic bacteria in many mammalian species (BULLEN et al., 1978; WeINBERG, 1978; Crosa, 1984), and several workers demonstrated that some iron compounds enhanced the virulence of bacteria in experimental infections (Bullen, 1981). In fish, the excess iron

* Present address: Aquaculture Department, Southeast Asian Fisheries Development Center, Tigbauan, Iloilo, Philippines is also supposed to constitute a predisposing factor to some bacterial infections as in mammals. However, the effects of excessive iron in hosts on the virulence of pathogens including $V$. anguillarum have been scarcely examined so far.

In the present investigation, the significance of iron compounds in enhancing the virulence of $V$. anguillarum was examined in Japanese eel (Anguilla japonica) and ayu, the former being less susceptible and the latter highly susceptible to the pathogen. . As the result, the virulence of $V$. anguillarum was apparently enhanced by a preinjection of iron compounds in the former fish species.

\section{Materials and Methods}

\section{Fish}

Japanese eels (40-110 $\mathrm{g}$ body weight) were obtained from private farms and ayu $(3-10 \mathrm{~g})$ were raised in experimental ponds of Hiroshima University from their juvenile stage. These material fish were acclimatized at about $20^{\circ} \mathrm{C}$ prior to every experiment and not fed through experimental periods. 


\section{Lethal toxicity of iron compounds to fish}

Three iron compounds, ferric ammonium citrate (designated as FAC), ferrous sulfate $\mathrm{FeSO}_{4} \cdot 7 \mathrm{H}_{2} \mathrm{O}$ (FS), and ferric chloride $\mathrm{FeCl}_{3} \cdot 6 \mathrm{H}_{2} \mathrm{O}$ (FC) were used for toxicity tests to eels, but for the test to ayu only FAC was used. Each solution of iron compounds in saline was filter-sterilized $(0.45 \mu \mathrm{m})$, and groups of five fish were injected with the various doses ranging from $5 \mu \mathrm{g}$ to $320 \mu \mathrm{g}$ per $\mathrm{g}$ of fish body weight intramuscularly (IM) for eels or intraperitoneally (IP) for ayu. Control fish received only saline injections. After injection, fish were maintained at $20^{\circ} \mathrm{C}$ and the $96 \mathrm{~h}$-median lethal dose $\left(\mathrm{LD}_{50}\right)$ was calculated by the method of REED and MuENCH (1938).

\section{Measurement of serum iron level}

Eels were IM-injected with varying doses of FAC $(4,10,80$, and $160 \mu \mathrm{g} / \mathrm{g})$ at $20^{\circ} \mathrm{C}$. Blood samples were obtained from the bulbus arteriosus of each 2 fish at 1,2, 4, and 7 days post-jnjection, and kept at room temperature for $2 \mathrm{~h}$ and followed by another $2 \mathrm{~h}$ at $4^{\circ} \mathrm{C}$. Serum was separated by centrifugation at $3,000 \mathrm{rpm}$ for $10 \mathrm{~min}$ and stored at $-20^{\circ} \mathrm{C}$ until used. Iron levels of serum were measured by an atomic absorption spectrophotometer (Hitachi Model 208) against iron standards.

\section{Virulence test}

A virulent strain PT-81049 (Serotype: J-O-1) of $V$. anguillarum, which was isolated from a diseased ayu in 1981, was cultured on nutrient agar (Eiken) at $25^{\circ} \mathrm{C}$ for $24 \mathrm{~h}$, and serial 10 -fold dilutions of the culture were made with sterile saline. Immediately after IM-injection (for eels) or IP-injection (for ayu) of iron compounds, a group of 5 fish was injected with each dilution of bacterial suspension $\left(10^{9}-10^{1} \mathrm{CFU} / \mathrm{m} l\right)$ and observed in tanks at $19-20^{\circ} \mathrm{C}$ for 7 days. In addition to injection challenge, ayu were challenged by another method, where fish were immersed in a bacterial suspension containing $10^{4}$ to $10^{2} \mathrm{CFU} /$ $\mathrm{m} l(1 \% \mathrm{NaCl})$ for $5 \mathrm{~min}$ with aeration. The spleen and liver materials of dead fish were examined bacteriologically, and only the mortalities due to $V$. anguillarum were counted in.

\section{Growth in fish serum}

Fish sera obtained from the bulbus arteriosus (eels) or the caudal artery (ayu) were 5-fold diluted with gelatin-veronal buffer containing $\mathrm{Ca}^{++}$and $\mathrm{Mg}^{++}\left(\mathrm{pH}\right.$ 7.4) and inactivated at $50^{\circ} \mathrm{C}$ for $30 \mathrm{~min}$ to destroy complement activities (NAKAI, 1985). A $24 \mathrm{~h}$ culture of $V$. anguillarum PT-81049 strain at $25^{\circ} \mathrm{C}$ was inoculated in each serum at a dose of $2 \times 10^{3} \mathrm{CFU} / \mathrm{m} l$ with or without FAC $(10 \mu \mathrm{g} / \mathrm{ml})$ and shake-cultured at $25^{\circ} \mathrm{C}$. After $6 \mathrm{~h}$ and $12 \mathrm{~h}$ of incubation, the viable cells were counted by spread-plate technique on nutrient agar.

\section{Results}

\section{$L D_{\square 0}$ of iron compounds to fish}

The $96 \mathrm{~h}-\mathrm{LD}_{50}$ values of FAC, FS, and FC to Japanese eels were 80,180 , and more than $320 \mu \mathrm{g} / \mathrm{g}$, respectively, and the value of FAC to ayu was $123 \mu \mathrm{g} / \mathrm{g}$ (Table 1 ).

\section{Serum iron level after FAC injection}

Iron levels in the serum of eels injected with varying FAC doses are shown in Table 2. The serum iron level of control fish was $1-2 \mu \mathrm{g} / \mathrm{ml}$. In each FAC injected group, maximum iron concentration was attained one day after injection and the levels were in proportion to the dose injected. These levels began to decline at day 2, and those of eels given 4 or $10 \mu \mathrm{g} / \mathrm{g}$ of FAC decreased to the

Table 1. $\mathrm{LD}_{50}$ of iron compounds to fish

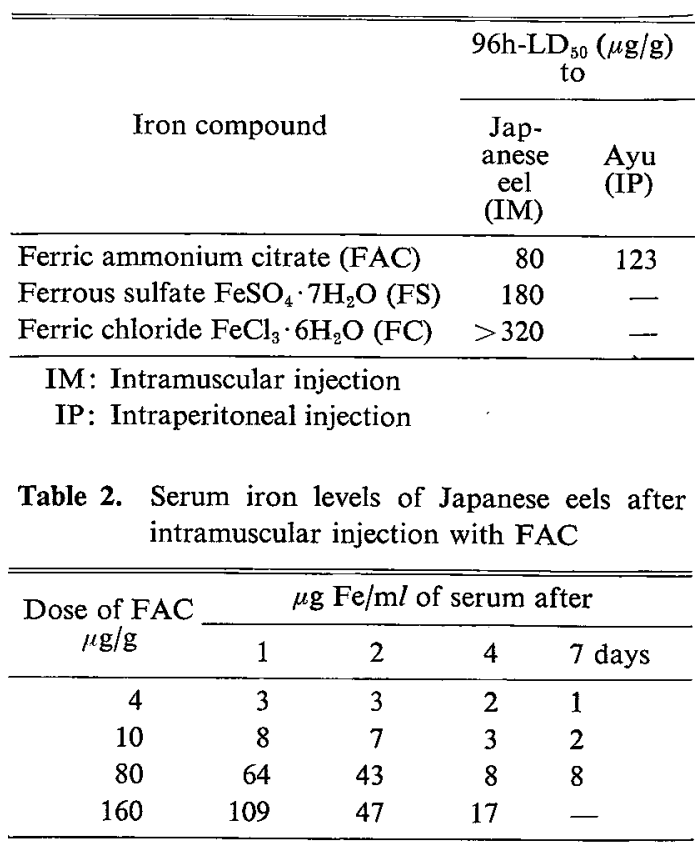


Table 3. Effects of FAC on the virulence of $V$. anguillarum PT-81049 strain to Japanese eel

\begin{tabular}{ccccccc}
\hline \multirow{2}{*}{$\begin{array}{c}\text { Dose of FAC } \\
\mu \mathrm{g} / \mathrm{g}\end{array}$} & \multicolumn{5}{c}{ Mortality (\%) after IM-injection of $V$. anguillarum with doses (CFU/100 g) } \\
\cline { 2 - 6 } (IM-injection) & $2.6 \times 10^{8}$ & $2.6 \times 10^{7}$ & $2.6 \times 10^{6}$ & $2.6 \times 10^{5}$ & $2.6 \times 10^{4}$ & $2.6 \times 10^{3}$ \\
\hline 0 & $93(14 / 15)$ & $13(2 / 15)$ & $0(0 / 15)$ & $0(0 / 15)$ & $0(0 / 15)$ \\
1 & & $80(4 / 5)$ & $0(0 / 5)$ & $0(0 / 5)$ & $0(0 / 5)$ \\
2 & $100(5 / 5)$ & $20(1 / 5)$ & $0(0 / 5)$ & $0(0 / 5)$ & \\
4 & & $100(5 / 5)$ & $80(4 / 5)$ & $40(2 / 5)$ & $0(0 / 5)$ & $50(5 / 10)$ \\
10 & $100(10 / 10)$ & $80(8 / 10)$ & $90(9 / 10)$ & $80(8 / 10)$ & $60(6 / 10)$ & 5 \\
\hline
\end{tabular}

IM: Intramuscular

Numbers in parenthesis: dead/tested

same level as control's up to day 7 .

\section{Effect of iron compounds on the virulence}

Table 3 shows the mortalities of the eels injected with various doses of FAC and $V$. anguillarum. As is obvious from the table, the iron injection greatly enhanced the virulence of the strain injected. The virulence-enhancing effect of FAC was dose-dependent, and the injection with the highest dose $(10 \mu \mathrm{g} / \mathrm{g})$ reduced the $\mathrm{LD}_{50}$ value of the pathogen from $10^{7.9}$ to $10^{4.2} \mathrm{CFU} /$ $100 \mathrm{~g}$. Fish died 2 to 4 days after infection in all experimental groups, showing hemorrhage at the injected muscle.

The effects of FAC, FS, and FC injections on the virulence of the strain are presented in Table 4. In this experiment, the amount of iron given to each eel except for two control groups was adjusted to the same level $(1.8 \mu \mathrm{g} / \mathrm{g}$ as $\mathrm{Fe})$ regardless of kinds of iron compounds and fish were IM-injected with a bacterial dose of $2.5 \times 10^{6} \mathrm{CFU} /$ $100 \mathrm{~g}$. The virulence-enhancing effect was de-

Table 4. Effects of three iron compounds on the virulence of $V$. anguillarum PT-81049 strain to Japanese eel

\begin{tabular}{|c|c|}
\hline $\begin{array}{l}\text { Iron compound (dose) } \\
\text { (IM-injection) }\end{array}$ & $\begin{array}{c}\text { Mortality }(\%) \text { after } \\
\text { IM-injection of } \\
V . \text { anguillarum } \\
\text { (dose } 2.5 \times \\
\left.10^{6} \mathrm{CFU} / 100 \mathrm{~g}\right)\end{array}$ \\
\hline $\mathrm{FAC}(10.0 \mu \mathrm{g} / \mathrm{g})$ & $80(8 / 10)$ \\
\hline FS $(9.0 \mu \mathrm{g} / \mathrm{g})$ & $90(9 / 10)$ \\
\hline $\mathrm{FC}(8.7 \mu \mathrm{g} / \mathrm{g})$ & $0(0 / 10)$ \\
\hline $\begin{array}{l}\mathrm{FC}(8.7 \mu \mathrm{g} / \mathrm{g})+ \\
\quad \text { citric acid }(9.0 \mu \mathrm{g} / \mathrm{g})\end{array}$ & $80(8 / 10)$ \\
\hline Control 1 (citric acid $9.0 \mu \mathrm{g} / \mathrm{g}$ ) & $0(0 / 10)$ \\
\hline Control 2 (saline) & $0(0 / 10)$ \\
\hline
\end{tabular}

IM: Intramuscular

Numbers in parenthesis: dead/tested monstrated by FAC ( $80 \%$ mortality) and FS $(90 \%)$ injections, but not by $\mathrm{FC}(0 \%)$. However, the mixture of citric acid and $\mathrm{FC}$ resulted in high mortality $(80 \%)$ of eels.

On the other hand, the virulence-enhancing effect of FAC $(10 \mu \mathrm{g} / \mathrm{g})$ in ayu was not so obvious as in the eels. The $\mathbf{L D}_{50}$ value in injection challenge was reduced only from $10^{1.3}$ to $10^{0.8}$ CFU/fish by injection of FAC (Table 5). When challenged by immersion, no effects of FAC injection were seen in the mortality of ayu (Table 6).

Table 5. Effects of FAC on the virulence of $V$. anguillarum PT-81049 strain to ayu in injection-challenge

\begin{tabular}{cccc}
\hline & \multicolumn{2}{c}{$\begin{array}{c}\text { Mortality (\%) after } \\
\text { IP-injection of } \\
\text { Dose of FAC } \\
\mu \mathrm{g} / \mathrm{g} \\
\text { (IP-injection) } \\
\text { doses (CFU/firum } \text { with }\end{array}$} \\
\cline { 2 - 4 } & $2.3 \times 10^{2}$ & $2.3 \times 10^{1}$ & $2.3 \times 10^{0}$ \\
\hline 0 & $96(23 / 24)$ & $52(13 / 25)$ & $8(2 / 25)$ \\
10 & $96(22 / 23)$ & $84(21 / 25)$ & $32(8 / 25)$ \\
\hline
\end{tabular}

IP: Intraperitoneal

Numbers in parenthesis: dead/tested

Table 6. Effects of FAC on the virulence of $V$. anguillarum PT-81049 strain to ayu in immersion-challenge

\begin{tabular}{cccc}
\hline \multirow{2}{*}{$\begin{array}{c}\text { Dose of FAC } \\
\mu \mathrm{g} / \mathrm{g} \\
\text { (IP-injection) }\end{array}$} & \multicolumn{2}{c}{$\begin{array}{c}\text { Mortality (\%) after } \\
\text { immersion-challenge with } \\
V \text {. anguillarum at cell } \\
\text { conc. (CFU/m })\end{array}$} \\
\cline { 2 - 4 } & $4.1 \times 10^{4}$ & $4.1 \times 10^{3}$ & $4.1 \times 10^{2}$ \\
\hline 0 & $93(14 / 15)$ & $47(7 / 15)$ & $0(0 / 15)$ \\
10 & $93(14 / 15)$ & $33(5 / 15)$ & $0(0 / 9)$ \\
\hline
\end{tabular}

IP: Intraperitoneal

Numbers in parenthesis: dead/tested 


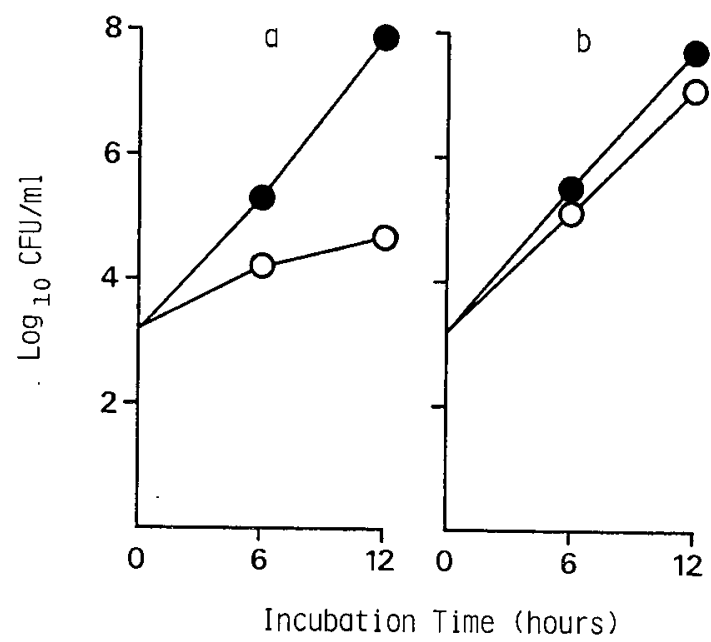

Fig. 1. Effects of FAC on the growth of $V$. anguillarum in Japanese eel serum (a) and ayu serum (b)

- with FAC $(10 \mu \mathrm{g} / \mathrm{m} l)$

$\mathrm{O}-\mathrm{O}$ : without FAC

\section{Effect of FAC on the growth}

Prior to the growth test of $V$. anguillarum using fish sera, the effect of FAC was examined in trypticase soy broth $(\mathrm{BBL}, 1 \% \mathrm{NaCl})$. The iron concentration of the medium was lowered to a level of $0.15 \mu \mathrm{g} \mathrm{Fe} / \mathrm{ml}$ by the method of SAKAZAKI (1978). As the result, the addition of FAC even at $1 \mu \mathrm{g} / \mathrm{m} l$ in the medium enhanced apparently the growth rate of $V$. anguillarum (data not shown).

Figure 1a shows that the addition of FAC $(10 \mu \mathrm{g} / \mathrm{m} l)$ to eel serum also increased $V$. anguillarum growth rate. After $12 \mathrm{~h}$ of incubation, the viable cell count in the serum with FAC $(8 \times$ $10^{7} \mathrm{CFU} / \mathrm{m} l$ ) was much higher than that in the serum without FAC $\left(3 \times 10^{4} \mathrm{CFU} / \mathrm{m} l\right)$. Similar growth-enhancing effect was obtained by an addition of FS or FC plus citric acid. While, the growth of $V$. anguillarum in ayu serum was little affected by FAC and the bacterium grew well in the serum without additional iron (Fig. 1b).

\section{Discussion}

In the present study, $96 \mathrm{~h}-\mathrm{LD}_{50}$ values of FAC to Japanese eels and ayu proved 80 and $123 \mu \mathrm{g} / \mathrm{g}$, respectively. HolbeIN et al. (1979) stated that FAC was lethal at the level of $12.5 \mu \mathrm{g} / \mathrm{g}$ to mice, thus the $\mathrm{LD}_{50}$ values obtained here for the two fish species are much higher than that for mice.

WRIGHT et al. (1981) showed that IP-injection of mice with $4 \mu \mathrm{g} / \mathrm{g}$ of FAC resulted in a lowering of the $\mathrm{LD}_{50}$ value of $V$. vulnificus from $6 \times 10^{6}$ to $1 \times 10$ cells and in a reduction in the time of death post-infection. The present study confirmed a similar effect of FAC on the virulence of $V$. anguillarum to Japanese eels, in which the $\mathbf{L D}_{50}$ of the bacterium was reduced from $10^{7.8}$ to $10^{4.2}$ CFU $/ 100 \mathrm{~g}$ by IM-injection with $10 \mu \mathrm{g} / \mathrm{g}$ of FAC (Table 3). The same effect was also found in FS injection but not in FC injection in spite of the same dose of Fe. The ineffectiveness of FC may be due to the lower solubility of this substance, because when the solubility was increased by addition of citric acid the mixture enhanced the virulence of the organism (Table 4). Although the possibility can not be totally ruled out that the enhancement of the virulence of $V$. anguillarum was brought about by lowered resistance of the host due to iron toxicity, the raised availability of free iron in the host seems to enhance the virulence of the pathogen. This was partly supported by the facts that the in vitro -growth of $V$. anguillarum was accelerated by an addition of FAC in eel serum (Fig. 1a).

Japanese eel is one of susceptible fishes to $V$. anguillarum, however, it should be noted that its susceptibility is far lower than that of ayu and vibriosis of eel is not so common in culture ponds in Japan. The present result, conversely, indicates that the natural resistance of the eel to the pathogen partly comes from the low level of free iron in this fish, and on that account, the iron injection had enhanced the virulence of $V$. anguillarum in eels. It must be confirmed that various iron-containing substances such as lysed erythrocytes, hemoglobin, and heme are also able to enhance the virulence of $V$. anguillarum as reported for some human pathogens (BULleN, 1981; KARUNASAGAR et al., 1984). The probable sources of excess iron or preceding conditions yielding the above-mentioned iron-containing substances have yet to be investigated in pond-cultured eels.

In the case of ayu, however, the FAC injection did not enhance the virulence of the pathogen so clearly (Tables 5, 6). A similar result was shown in coho salmon (Oncorhynchus kisutch), another highly susceptible fish to $V$. anguillarum, where 
FAC injection increased the virulence of a plasmid carrying $V$. anguillarum strain by only 1.3 -fold (Crosa, 1980). The fact that the growth rate of the organism in ayu serum was little accelerated by FAC addition (Fig. 1 b) possively indicates that ayu serum contains an enough amount of iron to let the bacterium proliferate. In an additional experiment, the iron level in ayu serum measured approximately 1-2 $\mu \mathrm{g} \mathrm{Fe} / \mathrm{m} l$, and this value is the same as that of Japanese eels. Thus, the difference in iron level available for $V$. anguillarum between eel and ayu may be due to the difference in the amount or the ability of iron-binding proteins such as transferrin (BULLEN, et al., 1978).

\section{References}

AOKI, T. and T. KITAO (1978): Vibriosis of ayu. Fish Pathol., 13, 19-24.

Bullen, J. J. (1981): The significance of iron in infection. Rev. Infect. Dis., 3, 1127-1138.

Bullen, J. J., H. J. Rogers and E. Griffiths (1978): Role of iron in bacterial infection. Curr. Topics Microbiol. Immunol., 80, 1-35.

CrosA, J. H. (1980): A plasmid associated with virulence in the marine fish pathogen Vibrio anguillarum specifies an iron-sequestering system. Nature, 284, 566-568.

Crosa, J. H. (1984): The relationship of plasmidmediated iron transport and bacterial virulence. Ann. Rev. Microbiol., 38, 69-89.

EVELYN, T. P. T. (1984): Immunization against pathogenic vibrios, p. 121-150. In Symposium on fish vaccination (P. de KInkelin ed.). O.I.E., Paris.

Holbein, B. E., K. W. F. Jericho and G. C. Likes (1979): Neisseria meningitidis infection in mice. Influence of iron, variations in virulence among strains, and pathology. Infect. Immun., 24, 545551.

Horne, M. T. (1982): The pathogenicity of Vibrio anguillarum (Bergman), p. 171-187. In Microbial diseases of fish (R. J. Roberts ed.). Academic Press, London.

Horne, M. T. and A. Baxendale (1983): The adhesion of Vibrio anguillarum to host tissues and its role in pathogenesis. J. Fish Dis., 6, 461-471.

Inamura, H., K. Muroga and T. NakaI (1984): Toxicity of extracellular products of Vibrio anguil- larum. Fish Pathol., 19, 89-96.

INAMURA, H., T. NAKAI and K. Muroga (1985): An extracellular protease produced by Virbio anguillarum. Bull. Japan. Soc. Sci. Fish., 51, 1915-1920. Jo, Y. (1981): Studies on Vibrio anguillarum infection in cultured ayu and its immunological prophylaxis. Shikoku Acta Medica, 37, 82-110.

Karunasagar, I., S. W. Joseph, R. M. Twedt, H. HADA and R. R. Colwell (1984): Enhancement of Vibrio parahaemolyticus virulence by lysed erythrocyte factor and iron. Infect. Immun., 46, 141144.

Kodama, H., M. Moustafa, T. Mikami and H. IzaWA (1985): Characterization of extracellular substance of Vibrio anguillarum toxic for rainbow trout and mice. Microbiol. Immunol., 29, 909-920.

MuNN, C. B. (1980): Production and properties of a haemolytic toxin by Vibrio anguillarum, p. 69-74. In Fish diseases. Third COPRAQ-Session (W. AHNE ed.). Springer-Verlag, Berlin.

NAKAI, T. (1985): Resistance of Pseudomonas anguilliseptica to bactericidal action of fish serum. Bull. Japan. Soc. Sci. Fish., 51, 1431-1436.

ReED, L. J. and H. Muench (1938): A simple method of estimating fifty percent endpoints. Am. $J$. Hygiene, 27, 493-497.

SAKAZAKI, R. (1978): Media for Corynebacterium, p. 258-286. In Bacterial culture media, vol. 2 . Kindai Shuppan, Tokyo.

Toranzo, A. E., J. L. Barja, R. R. Colwell, F. M. Hetrick and J. H. Crosa (1983): Haemagglutinating, haemolytic and cytotoxic activities of Vibrio anguillarum and related vibrios isolated from striped bass on the Atlantic coast. FEMS Microbiol. Letters, 18, 257-262.

Trust, T. J., I. D. Courtice, A. G. Khouri, J. H. Crosa and M. H. SCHIEwe (1981): Serum resistance and hemagglutination ability of marine vibrios pathogenic for fish. Infect. Immun., 34, 702-707.

UMBreIT, T. H. and M. R. TRIPP (1975): Characterization of the factors responsible for death of fish infected with Vibrio anguillarum. Can.J. Microbiol., 21, 1272-1274.

WeInberg, E. D. (1978): Iron and infection. Microbiol. Rev., 42, 45-66.

Wright, A. C., L. M. Simpson and J. D. Oliver (1981): Role of iron in the pathogenesis of Vibrio vulnificus infections. Infect. Immun., 34, 503-507. 